\title{
First record of Ornithodoros faccinii (Acari: Argasidae) on toads of genus Rhinella (Anura: Bufonidae) in Brazil
}

\author{
Primeiro registro de Ornithodoros faccinii (Acari: Argasidae) em sapos do gênero Rhinella no Brasil \\ Hermes Ribeiro Luz ${ }^{1}$; Bruna Barboza Bezerra ${ }^{2}$; Walter Flausino ${ }^{2}$; Arlei Marcili ${ }^{1,3}$; Sebastián Muñoz-Leal ${ }^{1}$; \\ João Luiz Horacio Faccini ${ }^{2}$

\begin{abstract}
${ }^{1}$ Departamento de Medicina Veterinária Preventiva e Saúde Animal, Escola de Medicina Veterinária e Ciência Animal, Universidade de São Paulo - USP, São Paulo, SP, Brasil

${ }^{2}$ Departamento de Parasitologia Animal, Universidade Federal Rural do Rio de Janeiro - UFRRJ, Seropédica, RJ, Brasil

${ }^{3}$ Programa de Medicina Animal e Bem-Estar, Universidade de Santo Amaro - UNISA, São Paulo, SP, Brasil
\end{abstract}

Received November 17, 2017

Accepted March 26, 2018

\begin{abstract}
Although a group of soft ticks (Argasidae) associated with amphibians was recently discovered in Brazilian rainforests, parasitism by these ticks on cold-blooded animals remains less common than on mammal and bird species. In this study, we identified ticks that were collected from toads that had been caught in December 2016 and January 2017, at Itinguçú waterfall ( $22^{\circ} 54^{\prime} 05^{\prime \prime}$ S; 435' $\left.30^{\prime \prime} \mathrm{W}\right)$ in the municipality of Itaguaí, state of Rio de Janeiro. Tick specimens were identified using a morphological and molecular approach. In total, twelve larvae of Ornithodoros ticks were collected from three individuals of Rhinella ornata and were identified as Ornithodoros faccinii. Our results include a longer 16S rRNA mitochondrial sequence for $O$. faccinii that supports its phylogenetic relatedness to Ornithodoros saraivai, and we report this tick species parasitizing Rhinella toads for the first time in Brazil.
\end{abstract}

Keywords: Ticks, Argasidae, Anurans, Rhinella, Brazil.

\section{Resumo}

Embora um grupo de carrapatos moles (Argasidae) associado a anfíbios tenha sido recentemente descoberto nas florestas brasileiras, o parasitismo por esses carrapatos em animais de sangue frio permanece menos comum do que nas espécies de mamíferos e aves. Neste estudo, identificamos carrapatos que foram coletados de sapos capturados em dezembro de 2016 e janeiro de 2017, na cachoeira de Itinguçú (2254’05” S; 4353’30” W) no município de Itaguaí, estado do Rio de Janeiro. Os espécimes de carrapatos foram identificados usando uma abordagem morfológica e molecular. No total, doze larvas de carrapatos Ornithodoros foram coletadas de três indivíduos de Rhinella ornata e foram identificadas como Ornithodoros faccinii. Nossos resultados incluem uma maior seqüência mitocondrial $16 S$ rRA para $O$. faccinii que suporta sua relação filogenética com Ornithodoros saraivai e relatamos esta espécie de carrapato parasitando sapos Rhinella pela primeira vez no Brasil.

Palavras-chave: Carrapatos, Argasidae, Anuros, Rhinella, Brasil.

\section{Introduction}

The fauna of anurans in Brazil is the largest in the world with more than 1000 extant species (IUCN, 2017; SBH, 2017). Of this total, less than $10 \%$ have been reported to present associations with ticks in this country. Amphibians of the families Bufonidae and Cycloramphidae have been found to act as the main associated hosts (LUZ \& FACCINI, 2013; GUGLIELMONE et al., 2014; BARROS-BATTESTI et al., 2015; MUÑOZ-LEAL et al., 2017b).

*Corresponding author: Hermes Ribeiro Luz. Departamento de Medicina Veterinária Preventiva e Saúde Animal, Faculdade de Medicina Veterinária e Zootecnia, Universidade de São Paulo - USP, Av. Dr. Orlando Marques de Paiva, 87, CEP 05508-270, Sáo Paulo, SP, Brasil. e-mail: hermesluz@usp.br
Ticks parasitizing anurans have been reported in the Brazilian biomes of the Cerrado, Caatinga, Mata Atlântica (Atlantic Forest) and Amazônia (Amazon region), and chiefly comprise hard ticks (Ixodidae) of the genus Amblyomma (WOEHL, 2002; DANTAS-TORRES et al., 2008; BARROS-BATTESTI et al., 2015; HORTA et al., 2015; LUZ et al., 2015). However, soft ticks (Argasidae) such as Ornithodoros faccinii Barros-Battesti, Landulfo \& Luz, 2015, and Ornithodoros saraivai Muñoz-Leal \& Labruna, 2017, have been recently added to the list, and have pointed towards the evolutionary possibility of a group that evolved in association with amphibians (MUNOZZ-LEAL et al., 2017b). 
Most Neotropical species of the family Argasidae have been recorded as parasitizing a wide variety of wild mammals, birds, reptiles and, to a lesser extent, amphibians (RAMOS et al., 2015; SPONCHIADO et al., 2015; LABRUNA et al., 2016; MUÑOZ-LEAL et al., 2016). Until now, only anurans of the families Bufonidae and Cycloramphidae have been recorded in association with soft ticks, restricted exclusively to species of the genus Ornithodoros (CAPRILES \& GAUD, 1977; RIVAS et al., 2012; BERMÚDEZ et al., 2013; BARROS-BATTESTI et al., 2015; MUNOZZ-LEAL et al., 2017b). Of the 211 species of soft ticks that have been described to date, 129 belong to the genus Ornithodoros, and five of them, namely Ornithodoros talaje (Guérin-Méneville, 1849), Ornithodoros puertoricensis Fox 1947, $O$. faccinii and $O$. saraivai, and an additional species that is morphologically related to the $O$. talaje group (RIVAS et al., 2012), have been recorded parasitizing amphibians in the Americas.

The aims of the current study were to provide the first report of $O$. faccinii parasitizing anurans of the family Bufonidae in Brazil and to reassess its phylogenetic position by means of a longer partial sequence of $16 S$ mitochondrial rRNA.

\section{Materials and Methods}

\section{Study site and toad-catching}

Ticks were collected from toads between December 2016 and January 2017, at Itinguçú waterfall in the municipality of Itaguaí, state of Rio de Janeiro, distant 30 meters (22 54 '05" S; $\left.43^{\circ} 53^{\prime} 30^{\prime \prime} \mathrm{W}\right)$ from the type locality of $O$. faccinii.

Anurans were caught manually through an active search, at dusk on alternate days, over a total six days, comprising 19 hours of sampling effort. All the animals thus caught were examined for tick infestation, and they were released at the same location where they had been caught, in order to cause minimal impact on the population of these hosts. The taxonomic nomenclature for amphibians that was used followed the system of the Brazilian Society of Herpetology (SBH, 2017), and the animals were caught and manipulated in accordance with the recommendations of the Brazilian Institute for the Environment and Renewable Natural Resources - Chico Mendes Institute for Biodiversity Conservation (IBAMA-ICMBio - number 36164-1).

\section{Collection and morphological identification of ticks}

Larval stages of soft ticks were removed with tweezers, kept in vials containing RNAlater (Sigma-Aldrich) and transported to the laboratory. For morphological and morphometric analyses, three ticks were slide-mounted in Hoyer's medium, and were photographed using an Olympus DP70 camera that was coupled to an Olympus BX40 optical microscope (Olympus Optical Co. Ltd., Japan). Specimens were identified to genus level as described by Barros-Battesti et al. (2013), and species-level diagnosis was performed by comparing the morphological traits of the slide-mounted ticks with those of other Neotropical Ornithodorinae (ENDRIS et al., 1989; BARROS-BATTESTI et al., 2015; MUNOOZ-LEAL et al., 2017b). Type species of $O$. faccinii from the Acari collection of the Butantan Institute (IBSP 10316) were examined in order to compare the number of dorsal setae.

\section{Molecular tools}

For molecular analyses, larval DNA was extracted using the bead-beater/phenol-chloroform method (SANTOLIN et al., 2013). Subsequently, conventional PCR as described by Mangold et al. (1998) was performed using the primers 3'- CCGGTCTCAACTCAGATCAAGT-5' (forward) and 3'-GCTCAATGATTTTTTAAATTGCTGT-5' (reverse), targeting a fragment of approximately $460 \mathrm{bp}$ from the mitochondrial sequence encoding $16 S$ rRNA. Sequencing of PCR products was performed by combining the same amplification primers, purified amplicons and BigDye Ready Reaction mix (ABI Corp) in an automated genetic analyzer (model 3500; ABI Corp). The sequences were assembled using Sequencher (Version 5.3, Genecodes Corporation, CA, USA). We used the BLAST search algorithm (ALTSCHUL et al., 1990) to determine closest gene identities.

\section{Phylogenetic analysis}

The sequences obtained for the mitochondrial 16S rRNA gene were aligned with another 60 Argasidae sequences retrieved from GenBank using Clustal X (THOMPSON et al., 1997), and were manually adjusted using the GeneDoc software. Sequences from Ixodes holocyclus Neumann, 1899 and Ixodes uriae White, 1852 were used as outgroups (accession numbers of all sequences are shown in the phylogenetic tree). The alignment was used to construct a phylogenetic tree using maximum parsimony, as implemented in PAUP version 4.0b10 (SWOFFORD 2002), with 500 bootstrap replicates, random stepwise addition to start trees (with random addition sequences) and TBR branch swapping. Bayesian analysis was performed using MrBayes v3.1.2 (HUELSENBECK \& RONQUIST, 2001) with four independent Markov chain runs for 1,000,000 metropolis-coupled MCMC generations, in which one tree was sampled every $100^{\text {th }}$ generation. The first $25 \%$ of the trees represented burn-in, and the remaining trees were used to calculate Bayesian posterior probabilities.

\section{Results}

We caught 15 anurans (seven specimens of Rhinella ornata (Spix, 1824) and eight of Thoropa miliaris (Spix, 1824), and a total of 12 larvae of the genus Ornithodoros were collected from three specimens of $R$. ornata (20\%) (Figure 1). Nine ticks were collected from the dorsal region of the hind limbs and three from the abdomen.

Three larvae were slide-mounted and were morphologically identified as $O$. faccinii, based on the following characters: idiosome with 11 pairs of dorsolateral setae and three pairs of central dorsal setae; seven (instead of six) pairs of dorsal anterolateral and four pairs of dorsal posterolateral setae; dorsal plate smooth, elongated, almost rectangular, with anterior and posterior margins rounded; ventral idiosome provided with seven pairs of setae 

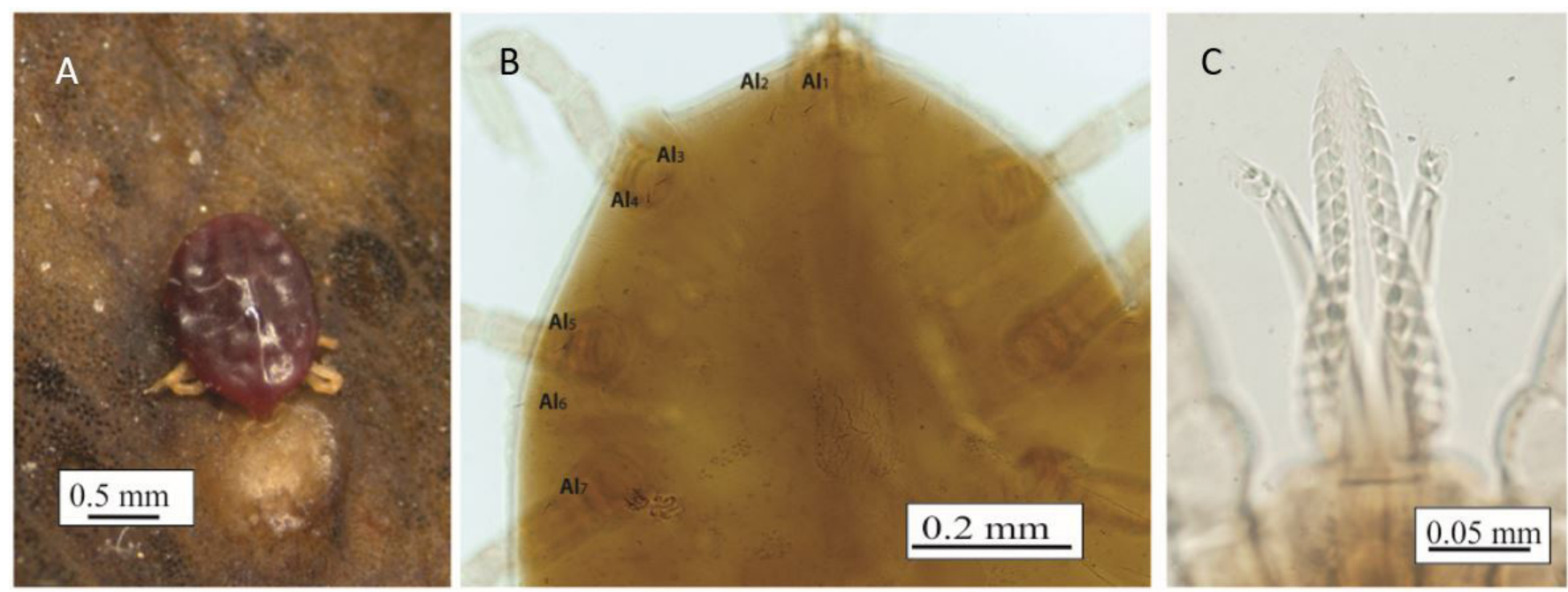

Figure 1. Larva of Ornithodoros faccinii: (A) larva parasitizing Rhinella ornata, note the subcutaneous abscess like at the attachment site; (B) dorsal view pointing seven pairs of dorsal anterolateral (Al) setae, and (C) hypostome.

(three pairs sternal, three circumanal and one postcoxal), plus one anal pair; posteromedian setae absent; hypostome pointed; and dental formula $3 / 3$ in the anterior third, then $2 / 2$ towards base (BARROS-BATTESTI et al., 2015) (Figure 1). Slide-mounted ticks were deposited in the "Danilo Gonçalves Saraiva" National Tick Collection (CNC) of the School of Veterinary Medicine of the University of São Paulo, São Paulo, Brazil, under accession number CNC-3514.

Morphological identifications of ticks were confirmed by means of molecular analyses, since DNA extracted from nine ticks retrieved a mitochondrial $16 \mathrm{~S}$ rRNA consensus sequence of $428 \mathrm{bp}$ that matched the shorter and sole 366-bp sequence of $O$. faccinit available in GenBank (KP861242), in which the nucleotides were $100 \%$ identical. The $16 \mathrm{~S}$ sequence obtained in this study was deposited in GenBank under the accession number KY661385.

The phylogenetic relationships between this tick and other Neotropical Argasidae were inferred from alignment of a partial fragment of the mitochondrial $16 \mathrm{~S}$ rDNA gene, including the longer sequence for $O$. faccinii that was obtained in the present study. This alignment showed that $O$. saraivai was a sister taxon clustering together within a larger clade composed of six other species of Ornithodoros (Figure 2).

\section{Discussion}

The record of $O$. faccinii larvae parasitizing anurans of the family Bufonidae is the first report of this in Brazil. Out of the 211 valid species of soft ticks worldwide, only representatives of the genus Ornithodoros have been recorded in association with amphibians. Indeed, early records of soft ticks on anurans in the Neotropical region documented larvae of a species of Ornithodoros that was morphologically related to the $O$. talaje group, and $O$. puertoricensis parasitizing Eleutherodactylus cooki Grant, 1932, in Puerto Rico (CAPRILES \& GAUD, 1977). Much more recently, Rivas et al. (2012) reported that they had collected approximately 200 larvae of an unidentified species of Ornithodoros from a single specimen of Rhinella arenarum (Hensel, 1867) in Argentina. Additionally, larval stages of $O$. puertoricensis were also reported by Bermúdez et al. (2013), collected from the axillae of a specimen of Rhinella marina (Linnaeus, 1758) in Panama. Lastly, soft ticks corresponding to the recently described $O$. faccinii and $O$. saraiva $i$ were recorded as parasites of T. miliaris and Cycloramphus boraceiensis Heyer, 1983 , in the states of Rio de Janeiro and São Paulo respectively (BARROS-BATTESTI et al., 2015; SÁ-HUNGARO et al., 2016; MUÑOZ-LEAL et al., 2017b). To date, these two species are the sole amphibian-associated soft ticks in Brazil. The frogs T. miliaris and $C$. boraceiensis are nidicolous endemic species of the Atlantic rainforest that frequent moist fissures in rocky environments near waterfalls (COCROFT \& HEYER, 1988; FEIO et al., 2006; AMPHIBIAWEB, 2017). However, specimens of T. miliaris were also observed beyond its usual habitat in rocky environments near waterfalls during the fieldwork, under damp leaves in the forest understory, and often sharing the same space with specimens of $R$. ornata. Occurrences of both amphibian species in the same microhabitat might explain the records of $O$. faccinii larvae on $R$. ornata. In turn, it cannot be ruled out that $O$. faccinii might also occur not only in association with lotic water environments, but also in the moisture of the Atlantic rainforest soil, where Rhinella toads live.

Although, in the original description of $O$. faccinii, Barros-Battesti et al. (2015) used the same primers as in the current study in order to sequence an approximately 460-bp fragment of mitochondrial $16 \mathrm{~S}$ rRNA, the sequence available for this species did not exceed $366 \mathrm{bp}$, and was $62 \mathrm{bp}$ smaller than the sequence presented in the current study, which was composed of 428 bp. Barros-Battesti et al. (2015) constructed a phylogenetic tree in which $O$. faccinii clustered in a clade with Ornithodoros capensis Neumann, 1901, and Ornithodoros sawaii Kitaoka \& Susuki, 1973. The first species, except Antarctica, occurs in all zoogeographic regions of the world, including the coasts of the Atlantic and Pacific oceans in the Neotropical Region, while 


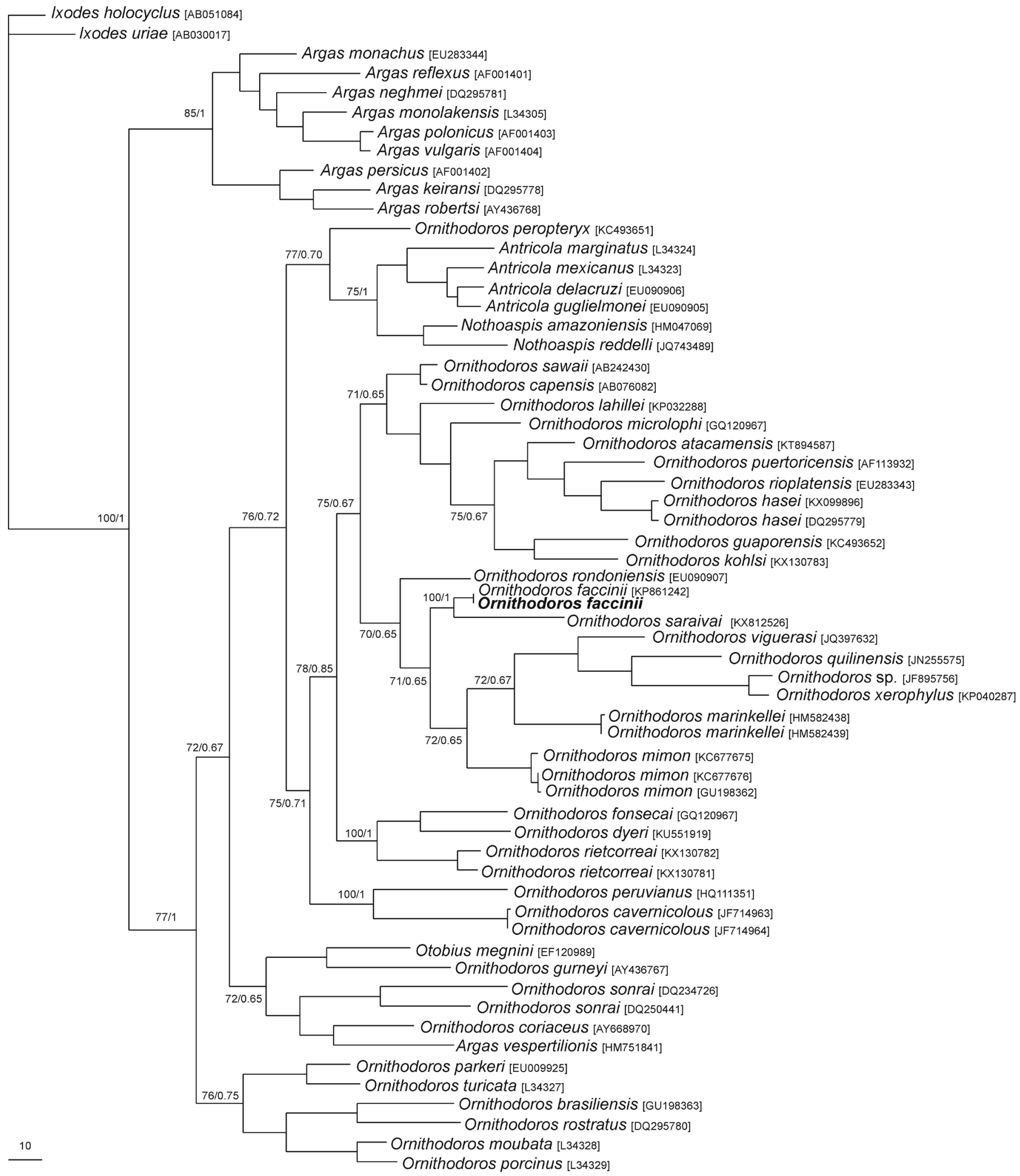

Figure 2. Phylogenetic tree inferred from 16S rDNA gene partial sequences, including the new sequence of Ornithodoros faccinii that was generates in the current study.

the latter was restricted to the Japanese islands (KIM et al., 2015; MUNOOZ-LEAL et al., 2017a). In this same analysis, it could be seen that these three species were grouped within a larger clade that included Ornithodoros marinkellei Kohls, Clifford \&
Jones 1969, Ornithodoros fonsecai (Labruna \& Venzal, 2009), Ornithodoros rioplatensis Venzal, Estrada-Peña \& Mangold, 2008, and $O$. puertoricensis. In turn, using the longer $16 \mathrm{~S}$ mitochondrial rRNA sequence (428 bp) that was obtained through the current 
study, our phylogenetic tree showed that $O$. faccinii forms a monophyletic group with $O$. saraivai and that it clusters within a larger clade that rather excludes $O$. capensis and $O$. sawaii from the group. In this way, the present study corroborates the phylogeny of Argasidae using partial sequences of this mitochondrial gene that was presented by Muñoz-Leal et al. (2017b).

Although, in the current study, larval stages of $O$. faccinii collected from $R$. ornata presented shared identity of at least $366 \mathrm{bp}$ with the sequence of $16 \mathrm{~S}$ mitochondrial rRNA gene that was characterized in the original description of this species (BARROS-BATTESTI et al., 2015), we observed one noteworthy difference in the dorsal setae, in comparing our material with the dorsal chaetotaxy reported in the original description of this species: seven instead of six pairs of dorsal anterolateral setae. In Ornithodoros larvae, dorsolateral setae appear arranged in one anterior group, chiefly composed by seven pairs, and one posterior group with a variable number. Therefore, presence of six pairs of dorsal anterolateral setae is a morphological characteristic that rapidly separates $O$. faccinii from every other Neotropical species of the genus Ornithodoros. Since the larva of $O$. faccinii was described exclusively from field-collected material, morphological analyses on laboratory-reared larvae that had not been exposed to tegumentary attrition caused by their microhabitat or by their host would need to be performed to evaluate whether this morphological dissimilarity is a naturally polymorphic characteristic.

\section{Acknowledgements}

To Dr. Douglas McIntosh for assistance in the molecular analyses, and to Stanley Fersen and Guilherme Furusawa for assistance in the fieldwork. Also to the São Paulo Research Foundation (FAPESP), National Council for Scientific and Technological Development (CNPq) and Coordination Office for Improvement of Higher-Education Personnel (Coordenação de Aperfeiçoamento de Pessoal de Nível Superior, CAPES) for funding. SML was funded through CONICYT Program for Training of Advance Human Capital (grant \#72140079).

\section{References}

Altschul SF, Gish W, Miller W, Myers EW, Lipman DJ. Basic local alignment search tool. J Mol Biol 1990; 215(3): 403-410. http://dx.doi. org/10.1016/S0022-2836(05)80360-2. PMid:2231712.

AmphibiaWeb. Information on amphibian biology and conservation [online]. 2017 [cited 2017 Jul 20]. Available from: http://amphibiaweb.org/

Barros-Battesti DM, Landulfo GA, Luz HR, Marcili A, Onofrio VC, Famadas KM. Ornithodoros faccinii n. sp. (Acari: Ixodida: Argasidae) parasitizing the frog Thoropa miliaris (Amphibia: Anura: Cycloramphidae) in Brazil. Parasit Vectors 2015; 8(1): 268. http://dx.doi.org/10.1186/ s13071-015-0877-3. PMid:25963542.

Barros-Battesti DM, Ramirez DG, Landulfo GA, Faccini JLH, DantasTorres F, Labruna MB, et al. Immature argasid ticks, diagnosis and keys for Neotropical region. Rev Bras Parasitol Vet 2013; 22(4): 443-456. http:// dx.doi.org/10.1590/S1984-29612013000400002. PMid:24473867.
Bermúdez SE, Miranda RJ, Kadoch SN. Reporte de larvas de Ornithodoros puertoricensis Fox 1947 (Ixodida: Argasidae) parasitando a Rhinella marina (L. 1758) (Anura: Bufonidae) en David, Chiriquí, Panamá. Puente Biol 2013; 5: 81-85.

Capriles JM, Gaud SM. The ticks in Puerto Rico (Arachnida: Acarina). J Agric Univ 1977; 61(3): 402-404.

Cocroft RB, Heyer WR. Notes on the frog genus Thoropa (Amphibia: Leptodactylidae) with a description of a new species (Thoropa saxatilis). Proc Biol Soc Wash 1988; 101(1): 209-220.

Dantas-Torres F, Oliveira-Filho EF, Soares FAM, Souza BOF, Valença RBP, Sá FB. Ticks infesting Amphibians and Reptiles in Pernambuco, Northeastern Brazil. Rev Bras Parasitol Vet 2008; 17(4): 218-221. http:// dx.doi.org/10.1590/S1984-29612008000400009. PMid:19265581.

Endris RG, Keirans JE, Robbins RG, Hess WR. Ornithodoros (Alectorobius) puertoricensis (Acari: Argasidae): redescription by scanning electron microscopy. J Med Entomol 1989; 26(3): 146-154. http://dx.doi. org/10.1093/jmedent/26.3.146. PMid:2724311.

Feio RN, Napoli MF, Caramaschi U. Considerações taxonômicas sobre Thoropa miliaris (Spix, 1824), com revalidação e redescrição de Thoropa taophora (Miranda-Ribeiro, 1923) (Amphibia, Anura, Leptodactylidae). Arq Mus Nac 2006; 64: 41-60.

Guglielmone AA, Robbins RG, Apanaskevich DA, Petney TN, EstradaPeña A, Horak IG. The hard ticks of the world: (Acari: Ixodida: Ixodidae). London: Springer; 2014. http://dx.doi.org/10.1007/978-94-007-7497-1.

Horta MC, Saraiva DG, Oliveira GM, Martins TF, Labruna MB. Rickettsia bellii in Amblyomma rotundatum ticks parasitizing Rhinella jimi from northeastern Brazil. Microbes Infect 2015; 17(11-12): 856-858. http:// dx.doi.org/10.1016/j.micinf.2015.08.010. PMid:26344601.

Huelsenbeck JP, Ronquist F. MRBAYES: Bayesian inference of phylogenetic trees. Bioinformatics 2001; 17(8): 754-755. http://dx.doi.org/10.1093/ bioinformatics/17.8.754. PMid:11524383.

International Union for Conservation of Nature - IUCN. Red list [online]. Cambridge: IUCN; 2017 [cited 2017 Jun 2017]. Available from: http:// www.iucnredlist.org/

Kim HC, Park CU, Park JH, Kwon YS, Yun SM, Lee WJ, et al. Ornithodoros sawaii Kitaoka and Suzuki (Acari: Ixodida: Argasidae) collected from nest soil and litter of Synthliboramphus antiquus and Hydrobates monorhis, on Chilbal Island, southwestern Jeollanam Province, Republic of Korea. Syst Appl Acarol 2015; 20(7): 721-730. http://dx.doi.org/10.11158/saa.20.7.1.

Labruna MB, Nava S, Marcili A, Barbieri ARM, Nunes PH, Horta $\mathrm{MC}$, et al. A new argasid tick species (Acari: Argasidae) associated with the rock cavy, Kerodon rupestris Wied-Neuwied (Rodentia: Caviidae), in a semiarid region of Brazil. Parasit Vectors 2016; 9(1): 511. http://dx.doi. org/10.1186/s13071-016-1796-7. PMid:27655282.

Luz HR, Faccini JLH, Silva HR. Patterns of parasitism by Amblyomma rotundatum (Ixodidae) on Rhinella schneideri (Bufonidae) in islands of São Francisco River, Minas Gerais, Brazil. Pesq Vet Bras 2015; 35(6): 579-582. http://dx.doi.org/10.1590/S0100-736X2015000600016.

Luz HR, Faccini JLH. Parasitismo por carrapatos em Anuros no Brasil. Revisão. Vet Zootec 2013; 20: 100-111.

Mangold AJ, Bargues MD, Mas-Coma S. Mitochondrial 16S rDNA sequences and phylogenetic relationships of species of Rhipicephalus and other tick genera among Metastriata (Acari: Ixodidae). Parasitol Res 1998; 84(6): 478-484. http://dx.doi.org/10.1007/s004360050433. PMid:9660138. 
Muñoz-Leal S, Dias RA, Abrahão CR, Labruna MB. The Ornithodoros capensis group (Acari: Argasidae): a morphological diagnosis and molecular characterization of $O$. capensis sensu stricto from Queimada Grande Island, Brazil. Syst Appl Acarol 2017a; 22(1): 28-41. http://dx.doi. org/10.11158/saa.22.1.5.

Muñoz-Leal S, Toledo LF, Venzal JM, Marcili A, Martins TF, Acosta ICL, et al. Description of a new soft tick species (Acari: Argasidae: Ornithodoros) associated with stream-breeding frogs (Anura: Cycloramphidae: Cycloramphus) in Brazil. Ticks Tick Borne Dis 2017b; 8(5): 682-692. http:// dx.doi.org/10.1016/j.ttbdis.2017.04.015. PMid:28506539.

Muñoz-Leal S, Venzal JM, González-Acuña D, Nava S, Lopes MG, Martins TF, et al. A new species of Ornithodoros (Acari: Argasidae) from desert areas of northern Chile. Ticks Tick Borne Dis 2016; 7(5): 901910. http://dx.doi.org/10.1016/j.ttbdis.2016.04.008. PMid:27132517.

Ramos DGS, Melo ALT, Martins TF, Alves AS, Pacheco TA, Pinto LB, et al. Rickettsial infection in ticks from wild birds from Cerrado and the Pantanal region of Mato Grosso Midwestern, Brazil. Ticks Tick Borne Dis 2015; 6(6): 836-842. http://dx.doi.org/10.1016/j.ttbdis.2015.07.013. PMid:26232933.

Rivas CJG, Castillo GN, Acosta JC, Venzal JM, Guglielmone AA. Primer reporte de parasitismo de una garrapata blanda del género Ornithodoros (Ixodida: Argasidae) sobre Rhinella arenarum (Anura: Bufonidae) en el departamento de Valle Fértil, San Juan, Argentina. Cuad Herpetol 2012; 26(2): 95-97.

Sá-Hungaro IJB, Luz HR, Lourenço EL, Silva HR, Faccini JLH, Famadas KM. Parasitism by Ornithodoros faccinii (Ixodida: Argasidae) on Thoropa miliaris (Anura: Cycloramphidae) in Brazil. Int J Acarol 2016; 43(3): 194-198. http://dx.doi.org/10.1080/01647954.2016.1260637.

Santolin ÍDAC, Famadas KM, McIntosh D. Detection and identification of Rickettsia agents in ticks collected from wild birds in Brazil by polymerase chain reaction-restriction fragment length polymorphism (PCR-RFLP) analysis. Rev Bras Med Vet 2013; 35(S2): 68-73.

SBH - Sociedade Brasileira de Herpetologia. Lista de espécies de anfíbios do Brasil [online]. SBH; 2017 [cited 2017 Jun 2017]. Available from: http://www.sbherpetologia.org.br.checklist/anfíbios.htm

Sponchiado J, Melo GL, Martins TF, Krawczak FS, Labruna MB, Cáceres NC. Association patterns of ticks (Acari: Ixodida: Ixodidae, Argasidae) of small mammals in Cerrado fragments, western Brazil. Exp Appl Acarol 2015; 65(3): 389-401. http://dx.doi.org/10.1007/s10493-014-9877-9. PMid:25633262.

Swofford DL. Phylogenetic analysis using parsimony ( ${ }^{*}$ and other methods). Version 4.b10. Sunderland, Massachusetts: Sinauer Associates; 2002.

Thompson JD, Gibson TJ, Plewniak F, Jeanmougin F, Higgins DG. The CLUSTAL X windows interface: flexible strategies for multiple sequence alignment aided by quality analysis tools. Nucleic Acids Res 1997; 25(24): 4876-4882. http://dx.doi.org/10.1093/nar/25.24.4876. PMid:9396791.

Woehl G Jr. Infestação de Amblyomma rotundatum (Koch) (Acari, Ixodidae) em sapos Bufo ictericus (Spix) (Amphibia, Bufonidae): novo registro de hospedeiro. Rev Bras Zool 2002; 19(2):329-333. http://dx.doi. org/10.1590/S0101-81752002000200003. 